\title{
Letter to the Editor: Menkes Metallothionein and Copper Metabolism
}

\author{
OWEN M. RENNERT AND WAI-YEE CHAN
}

\author{
Section of Genetics, Endocrinology and Melabolism and Departments of Pediarrics and Molecular Biology and \\ Biochemistry, University of Oklahoma Health Sciences Center, Oklahoma City, Oklahoma, USA
}

We read with great interest ${ }^{64} \mathrm{Cu}$ Metabolism in Menkes and Normal Skin Fibroblasts by Beratis et al. (1). We were particularly pleased with this article because it has verified work that we have previously presented on defective efflux of copper in Menkes kinky hair syndrome fibroblasts (2-4). There are several manuscripts presently in press (5-7) which present greater detail on the uptake and efflux processes involved in ${ }^{\star 4} \mathrm{Cu}$ and radiolabeled cadmium transport in fibroblasts from patients with Menkes kinky hair disease.

These reported studies have validated that Menkes kinky hair disease cells contain at least twice the intracellular copper of normal fibroblasts at medium copper concentrations below $20 \mu \mathrm{g} /$ ml. Death of Menkes kinky hair disease fibroblasts occur at medium copper concentrations between 15 and $20 \mu \mathrm{g} / \mathrm{ml}$, well below the toxic level for normal fibroblasts. Differences in the intracellular copper concentration, as well as the cell toxicity achieved by increasing medium copper concentrations, suggested to us that a regulatory mechanism for intracellular copper iransport was defective in normal fibroblasts when copper concentrations above $30 \mu \mathrm{g} / \mathrm{ml}$ were achieved. This phenomenon in normal cells was comparable to that seen in Menkes kinky hair disease fibroblast at all medium copper concentrations.

Intracellular cadmium concentrations of Menkes kinky hair disease fibroblasts were similar to that of normal cells $(23.6 \pm 6.4$ $\mathrm{ng} / \mathrm{mg}$ cell protein vs. $23.5 \pm 9.3 \mathrm{ng} / \mathrm{mg}$ cell protein) in basal medium, but always were higher at other medium cadmium concentrations $(0.1-1.5 \mu \mathrm{g} / \mathrm{ml}$ ), indicating an increased cadmium uptake by Menkes kinky hair disease cells.

By using ${ }^{64} \mathrm{Cu}$ for uptake studies, it was demonstrated that within the first hour copper uptake was three times as great in Menkes kinky hair disease cells as that in normal cells, while that of ${ }^{109} \mathrm{Cd}$ was about the same in both types of cells. Subsequent uptake of both radionuclides was higher in Menkes kinky hair disease cells than in normal cells.

Effluxes of ${ }^{64} \mathrm{Cu}$ and ${ }^{109} \mathrm{Cd}$ in both Menkes kinky hair disease and normal cells were studied by pulse-labeling techniques with radionuclides for $20 \mathrm{hr}$ and subsequently chased with nonradioactive medium. At both 37 and $4^{\circ}$, Menkes kinky hair disease cells demonstrated a higher retention of both radionuclides than did normal cells, indicating an impairment of efflux of both metals in Menkes kinky hair disease cells. Lowering the temperature did not increase the percentage of retention of either radionuclide in the two types of cells, implying that the efflux process was not energy requiring.

Inducibility of metallothioneins in Menkes kinky hair disease cells by copper and cadmium was investigated utilizing $L-\left[{ }^{35} S\right]-$ cystine in the presence of both copper and cadmium. ${ }^{64} \mathrm{Cu}$ failed, while ${ }^{109} \mathrm{Cd}$ succeeded in inducing metallothionein in both normal and Menkes kinky hair disease fibroblasts. However, the metallothionein induced by cadmium in Menkes kinky hair disease cells appeared to have a lower molecular weight than that in normal cells.

To explore further the potential role of metallothionein in the copper transport deficit of Menkes kinky hair disease cells, partially purified metallothionein (MT-I and MT-2) from one Menkes kinky hair disease and two normal livers were analyzed. Menkes kinky hair disease metallothioneins demonstrated reduced cadmium, copper, zinc, and sulfhydryl group content. Isotope exchange studies, carried out by incubating native metallothioneins with ${ }^{64} \mathrm{Cu}$ or ${ }^{109} \mathrm{Cd}$, demonstrated decreased affinity for copper and an increased affinity for cadmium in both Menkes kinky hair disease metallothioneins.

We believe that these observations implied an abnormality in Menkes kinky hair disease fibroblast copper and cadmium transport which was associated with structural abnormalities in metallothioneins. We proposed an hypothesis in which metallothionein functions as a carijer by combining with cations and carrying them to the site of excretion.

We submit these comments in reference to the article by Beratis et al. (1) because we believe that our data and theirs are somewhat divergent with regard to several points. First, we did not find significant radiolabeled copper bound to large molecular weight components in either normal or Menkes kinky hair disease fibroblasts. Second, in the speculation of the paper by these authors, we disagree with their suggestion that increased binding capacity of low-molecular weight copper transport proteins (metallothioneins) would account for the copper transport defect in this disorder.

Additionally, our group previously reported (8) that intracellular copper concentrations in brain are significantly below those of control tissues. Therefore, we would question their statement suggesting that copper concentration in whole brain is normal. The transport studies in our previously cited references have been performed at more than the two time points (6 and $24 \mathrm{hr}$ ) reported by Beratis et al. (1), though the conclusions are basically the same the distinctions in efflux do not quite follow the time course proposed by these authors.

Finally, on our experiments cell toxicity was induced in both normal and Menkes kinky hair disease fibroblasts at concenirations well below $60 \mu \mathrm{g} / \mathrm{ml}$ of copper.

In general we agree with the experimental data reported by Beratis et al. (1), but would propose somewhat different postulations to explain the phenomenon observed in Menkes kinky hair disease fibroblasts.

Thank you for allowing us the opportunity to express these opinions.

\section{REFERENCES AND NOTES}

1. Beratis, N, $G_{n}$ Price, P.. LaBadie, $G_{n}$ and Hirschhorn, $K_{\text {. }}{ }^{\text {Cud }} \mathrm{Cu}$ metabolism in Menkes and normal cultured skin fibroblasts. Pediatr. Res., 12: 699 (IS78).

2. Chan, W. Y., Garnica, A. D., and Rennert, O. M.: Defective metallothionein in kinky hair syndrome fibroblasts. Pediatr. Res.. II: 453 (1977).

3. Chan, W, Y, Garnica, A, D., and Rennert, O. M.: Studies of ${ }^{61} \mathrm{Cu}$ and ${ }^{1{ }^{12} \mathrm{Cd}}$ efflux and uptake in Menkes kinky hair (MKHS) fibroblasis. Pediatc. Res., II: $453(1977)$.

4. Chan, W. Y., Garnica, A. D., and Rennert. O. M.: Defective metallothionein and 
copper accumulation in Menkes kinky hair syndrome (MKHS) fibrobiasts. American Society of Human Genetics, San Diego, CA, p. 29A, October 19-22, [977.

5. Chan, W. Y., Gamica, A. D., and Rennert, O. M.: Cell culture studies in Menkes kinky hait disease. Clin. Chim. Acta (in press)

6. Chan, W. Y., Garnica, A. D., and Renner, O. M.: Metal-binding studies of metallohioneins in Menkes kinky hair disease. Clin. Chim. Acta (in press).

7. Garnica, A. D., Chan, W. Y., and Rennert, O. M.: Role of metallothioneins in copper transport in patients with Menkes syndrome. Ann. Lab. Clin. Sci. (in press).

8. Rennert. O. M. and Chan, W. Y.: Menkes kinky hair syndrome: is it a trealable disorder? Clin. Genel., /1: 154 (1977).

Copyright $\odot 1979$ lntemational Pediatric Research Foundation, lac.

Printed in U.S.A. 0031-3998/79/1303-0204\$02.00/0 